\title{
Pengaruh Gangguan Tidur dan Peranan Sitokin terhadap Luaran Stroke Iskemik
}

\author{
Daswara Djajasasmita \\ Departemen Neurologi Fakultas Kedokteran Universitas Jenderal Achmad Yani-Cimahi
}

\begin{abstract}
Abstrak
Stroke merupakan penyebab kematian kedua di dunia. Sebanyak 15,4\% dari seluruh kematian di Indonesia disebabkan oleh stroke. Prevalensi penyakit stroke meningkat dari tahun ke tahun dan akan menimbulkan masalah di bidang kesehatan. Salah satu faktor yang dapat memperburuk penyakit stroke, diantaranya adalah gangguan tidur. Tujuan penulisan artikel ini adalah untuk mengetahui hubungan antara gangguan tidur dan pengaruh sitokin terhadap luaran stroke iskemik. Stroke iskemik akibat aterosklerotik dengan adanya hipoksia pada neuron akan memicu pelepasan sitokin, termasuk tumor necrosis factor-alpha (TNF- $\alpha$ ) dan interleukin-10 (IL-10) dari neuron dan sel glial. Sitokin juga berpengaruh terhadap pola tidur seperti nerve growth factor (NGF) menginduksi nonrapid eye movement sleep (NREM) dan rapid eye movement sleep (REM). Gangguan tidur terutama sleep apnea mempunyai risiko yang lebih besar terhadap kejadian stroke atau risiko kematian oleh sebab apapun. Proses yang terjadi pada stroke iskemik akut menimbulkan respon inflamasi, proses inflamasi ini seperti pedang bermata dua karena di satu sisi menimbulkan kerusakan yang lebih luas, namun di sisi lain dapat bertindak membantu perbaikan. Peningkatan produksi sitokin seperti interleukin-10 (IL-10), IL-6, dan C-reactive protein (CRP) akan menimbulkan luaran yang buruk pada penderita stroke.
\end{abstract}

Kata kunci: gangguan tidur, luaran, sitokin, stroke iskemik

JNI 2021; 10 (1): 63-70

\section{The Effect of Sleep Disturbances and The Role of Cytokines on The Outcome of Stroke}

\begin{abstract}
Stroke is the second cause of death in the world. As many as $15.4 \%$ of all deaths in Indonesia are caused by strokes. The prevalence of stroke increases from year to year and will cause problems in the health sector. One of the factors can exacerbate stroke, including sleep disturbances. The aim of this article is to examine the relationship between sleep disturbances and the effect of cytokines on ischemic stroke outcome. Ischemic stroke due to atherosclerosis in the presence of hypoxia in neuron will result in the release of cytokines, including tumor necrosis factor-alpha (TNF- $\alpha$ ) and interleukin-10 (IL-10) from neurons and glial cells. Cytokines also influence sleep patterns such as nerve growth factor (NGF) inducing non-rapid eye movement sleep (NREM) and rapid eye movement sleep (REM). Sleep disorders, especially sleep apnea, have a greater risk of stroke or risk of death for any cause. The process that occurs in acute ischemic stroke causes an inflammatory response, this inflammatory process is like a double-edged sword because on the one hand it causes more extensive damage, but on the other hand it can act help repair. Increased production of cytokines such as interleukin-10 (IL-10), IL-6, and C-reactive protein (CRP) will lead to poor outcomein stroke patients.
\end{abstract}

Key words: sleep disturbances, outcome, cytokines, ischemic Stroke

JNI 2021; 10 (1): 63-70

This article is licensed under a
Creative Commons Attribution-NonCommercial-ShareAlike 4.0 International License.

ODaswara Djajasasmita (2021) under the CC-BY-NC-SA license 


\section{Pendahuluan}

Stroke merupakan masalah kesehatan global yang menjadi salah satu penyebab utama kematian dan kecacatan orang dewasa di seluruh dunia, dan menempati urutan kedua setelah penyakit jantung iskemik. ${ }^{1,2}$ Di Indonesia sebanyak 15,4\% dari seluruh kematian disebabkan oleh stroke. Prevalensi penyakit stroke berdasarkan hasil riset kesehatan dasar (Riskesdas) tahun 2018 meningkat dibandingkan tahun 2013 yaitu dari $7 \%$ menjadi 10,9\%. Secara nasional, prevalensi stroke di Indonesia tahun 2018 berdasarkan diagnosis dokter penduduk umur $\geq 15$ tahun sebesar $10,9 \%$, atau diperkirakan sebanyak 2.120 .362 orang. ${ }^{3}$ Menurut World Health Organization (WHO), stroke didefinisikan sebagai disfungsi otak yang terjadi secara mendadak baik fokal atau difus akibat gangguan pembuluh darah otak yang berakhir lebih dari 24 jam dan dapat menimbulkan kecacatan atau kematian., ${ }^{4,5}$ Stroke dibagi menjadi dua tipe yaitu stroke iskemik dan stroke hemoragik. Stroke iskemik lebih sering terjadi dibandingkan stroke hemoragik yaitu sekitar $85 \%{ }^{2,5,6,7}$

Peradangan setelah stroke iskemik akut dianggap sebagai proses patologis yang menimbulkan serangkaian peristiwa sekunder yang merugikan karena akan menyebabkan kerusakan sawar darah otak (blood-brain barrier/BBB). Sel imun perifer yang teraktivasi termasuk neutrophil dan sel-T kemudian dapat melewati BBB dan terakumulasi dilokasi cedera. ${ }^{6}$ Namun, respon inflamasi di jaringan otak, setelah stroke iskemik, berkontribusi pada perkembangan cedera otak iskemik dan eksaserbasi neurologis. Kemokin, sitokin yang diproduksi oleh sel mikroglial yang menetap dan sel imun yang menginfiltrasi, dapat menarik dan mengaktifkan leukosit. Beberapa kemokin bahkan mampu merekrut sel nonimun seperti sel induk saraf (Neural stem cells/ NSCs), sel saraf progenitor (Neural progenitor Cells/NPCs), sel endotel dan sel stroma sumsum tulang (Bone Marrow Mesenchymal Stem Cells/ BMSCS) ke lokasi lesi yang dapat memberikan dampak menguntungkan pada perlindungan dan pemulihan. ${ }^{7,8}$ Produksi sitokin meningkat pada pasien stroke. Pada otak, sitokin diekspresikan tidak hanya pada sel sistem imun, tetapi juga dihasilkan oleh sel yang terdapat pada otak seperti neuron dan glial. Sitokin yang berperan dalam proses inflamasi pada stroke iskemik akut adalah tumor necrosis factor- $\alpha$ (TNF- $\alpha$ ), interleukin$1 \beta$ (IL-1 $\beta$ ), IL-6, IL-20, IL-10 dan TGF- $\beta$. IL-6 diketahui sebagai pro-inflamasi juga sebagai neurotrofik dan memiliki kemampuan untuk regenerasi setelah kejadian iskemia serebral. IL-10 umumnya dipandang sebagai sitokin anti-inflamasi yang membantu menahan sitokin pro-inflamasi dan menekan ekspresi reseptor sitokin dan aktivasi reseptor. ${ }^{7}$ Kadar sitokin pro-inflamasi yang tinggi dan kadar sitokin antiinflamasi yang rendah dihubungkan dengan luasnya infark dan hasil klinis yang buruk. Suatu penelitian telah menunjukkan bahwa penggunaan agen anti-inflamasi seperti IL-1Ra dan IL10 memberikan hasil luaran stroke yang lebih baik. ${ }^{7}$ Risiko terkena stroke lebih besar terjadi pada pasen dengan gangguan tidur. Prevalensi gangguan tidur-bangun dilaporkan sebesar 20$40 \%$ pada pasen yang terkena stroke. Kualitas tidur mempengaruhi keparahan dan prognosis stroke. Di Indonesia, masih sedikit data yang dipublikasi mengenai pengaruh kualitas tidur terhadap keparahan stroke akut. ${ }^{1}$ Sepertiga orang dewasa Amerika Serikat melaporkan tidur kurang dari tujuh jam per malam, dan 50-70 juta orang mengalami gangguan tidur. Hubungan antara gangguan tidur dan faktor risiko vaskular sebagai penyebab stroke telah didokumentasikan dengan baik, tetapi belum sepenuhnya dipahami. Gangguan tidur dapat berkontribusi terhadap kelainan pembuluh darah pada pasen stroke melalui beberapa mekanisme baik langsung atau tidak langsung. Selain itu, konsekuensi dari gangguan tidur yang tidak diobati seperti disfungsi kognitif, perubahan suasana hati, mengantuk, dan kelelahan dapat menghambat pemulihan stroke, memperpanjang masa tinggal di rumah sakit, dan mempengaruhi hasil stroke dan kekambuhan stroke. ${ }^{10}$ Gangguan tidur ini dapat bermanifestasi dalam beberapa bentuk tergantung pada defisit neurologik spesifik yang ditimbulkan. Sleep-disorder breathing (SDB) terutama obstructive sleep apnea syndrome (OSAS) dan nocturnal oxygen desaturation merupakan gangguan tidur yang paling banyak 
ditemukan pada stroke akut $(>50 \%)$. OSAS sendiri sudah dikategorikan sebagai faktor risiko stroke dan kebersamaannya dengan stroke akan meningkatkan risiko terjadinya stroke berikutnya. Peningkatan derajat berat-ringannya sleep apnea diketahui berhubungan dengan peningkatan risiko stroke dan kematian. ${ }^{1}$ Kualitas tidur yang buruk dapat mempengaruhi derajat disabilitas pada pasien stroke. Untuk mengevaluasi tingkat keparahan stroke digunakan instrument standar pengukuran menurut The National Institutes of Health Stroke Scale (NIHSS) yang merupakan skala kuantitatif yang spesifik untuk stroke yang menevaluasi derajat kesadaran, fungsi Bahasa, neglect, lapangan pandang, pergerakan mata, kelumpuhan wajah, kekuatan motorik, fungsi sensorik, dan koordinasi. Dari hasil penelusuran literatur tersebut penulis ingin melihat hubungan antara sitokin yang dihasilkan pada saat kejadian stroke iskemik akut dengan sitokin yang dihasilkan akibat adanya gangguan tidur yang akan memperburuk luaran stroke.

\section{Stroke}

Stroke iskemik disebabkan oleh terputusnya atau penurunan suplai darah ke otak yang signifikan, dapat menyebabkan perubahan metabolik dan molekuler yang mengakibatkan gangguan fungsional dan kerusakan morfologis. ${ }^{11}$ Aliran darah otak normal (Cerebral blood flow/CBF) yaitu sekitar $50-60 \mathrm{ml} / 100 \mathrm{gr} / \mathrm{menit}$. Penurunan CBF di bawah $20 \mathrm{ml} / 100 \mathrm{gr} /$ menit menyebabkan gangguan listrik otak dan apabila kurang dari $10 \mathrm{ml} / 100 \mathrm{gr} / \mathrm{menit}$ menyebabkan cedera saraf ireversibel. Kurangnya sirkulasi darah ke otak menghilangkan glukosa dan oksigen yang diperlukan neuron untuk memancarkan impuls. ${ }^{2,5}$ Kebutuhan energi jaringan saraf sangat tinggi dan kecukupan pasokan darah harus dipertahankan secara konstan. Otak lakilaki dewasa normal yang mengandung sekitar 130 miliar neuron hanya terdiri dari $2 \%$ dari total massa tubuh, namun mengkonsumsi saat istirahat sekitar $20 \%$ dari total konsumsi oksigen basal tubuh yang dipasok oleh $16 \%$ dari output darah jantung. ${ }^{11}$ Faktor risiko kejadian stroke iskemik dibagi menjadi faktor yang tidak dapat dimodifikasi (non-modifiable risk factors) seperti umur, jenis kelamin, ras, genetik, dan riwayat Transient Ischemic Attack (TIA), dan faktor yang dapat dimodifikasi (modifiable risk factors) seperti hipertensi, diabetes, kolesterol tinggi (hiperkolesterolemia), perilaku merokok, obesitas, penyakit jantung, konsumsi alkohol berlebihan, aterosklerosis, penyalahgunaan obat, dan gangguan pernapasan saat tidur. ${ }^{3,12,13}$

\section{Patofisiologi Stroke iskemik}

Stroke iskemik merupakan tipe stroke yang paling sering terjadi. Stroke tipe ini disebabkan oleh terjadinya penyumbatan pembuluh darah pada pembuluh darah leher atau otak. Stroke iskemik menyebabkan hipoperfusi area otak yang memulai serangkaian peristiwa kompleks, yaitu eksitotoksisitas, stress oksidatif, cedera mikrovaskuler, disfungsi sawar darah otak, dan inflamasi pasca iskemik yang pada akhirnya menyebabkan kematian sel neuron, glia, dan sel endotel. Derajat dan lamanya iskemik menggambarkan luasnya kerusakan otak. Cedera saraf akibat hipoksia-iskemik dipengaruhi oleh pelepasan neurotransmitter eksitatorik terutama glutamat dan aspartat di otak. Glutamat yang dilepaskan di sinap akan menyebabkan pembukaan kanal kalsium. Influks kalsium menyebabkan aktivasi serangkaian

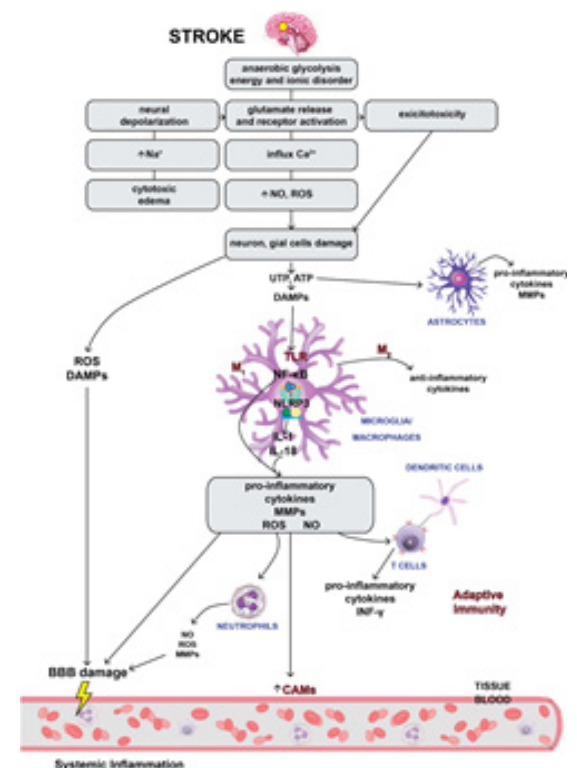

Gambar 1. Patomekanisme Kerusakan Otak Iskemik. $^{14}$ 
enzim destruksi seperti protease dan lipase yang memungkinkan pelepasan sitokin dan mediator inflamasi lainnya yang menyebabkan hilangnya integritas seluler. Dalam 30 menit setelah iskemik dan reperfusi, leukosit yang direkrut ke area iskemik mengaktifkan mediator inflamasi seperti radikal bebas oksigen (Reactive Oxygen Species/ ROS), sitokin, dan asam nitrat. ${ }^{5,14}$

\section{Respon Inflamasi pada Cedera Otak}

Iskemik fokal menimbulkan respon inflamasi yang kuat dimulai beberapa jam setelah onset yang melibatkan aktivasi mikroglia dan astrosit serta masuknya sel hematogen yang direkrut oleh pengaktifan sitokin, molekul adhesi, dan kemokin melintasi dinding pembuluh darah yang diaktifkan. Sel-sel otak yang dirangsang kemudian berkomunikasi satu sama lain melalui jaringan kompleks pensinyalan parakrin dan autokrin. Pembuluh darah otak adalah yang pertama kali terkena gangguan iskemik, dan reaksinya terhadap cedera menentukan tahap untuk respon inflamasi. Produksi sitokin, seperti TNF- $\alpha$ dan IL-6, dalam sel vaskuler dan mikroglia makrofag perivaskuler meningkatkan ekspresi molekul adhesi (misalnya Intercellular Adhesion Molecule-1 (ICAM-1), $\mathrm{P}$ dan E-selektin). Sebagai kekebalan utama otak, mikroglia yang diaktifkan berubah menjadi makrofag dan terakumulasi di zona perbatasan dan bersama dengan makrofag yang dibawa darah untuk membersihkan puing-puing dan sel mati dan menghasilkan mediator pro-inflamasi dan molekul beracun. Molekul yang dilepaskan sel otak yang terluka berkontribusi pada respon inflamasi. ${ }^{5,8}$

\section{Sitokin}

Sitokin merupakan protein nonstruktural kecil dengan berat molekul antara 8000 sampai 40.000 $\mathrm{Da}$, disekresi oleh sel imun (seperti limfosit $\mathrm{T}$, makrofag, natural killer cells), dan sel non imun (seperti sel schwann dan fibroblast). Salah satu fungsi utama dari sitokin adalah meregulasi diferensiasi sel $\mathrm{T}$, dari undifferentiated cells menjadi Th1 dan Th2, sel T regulator, dan sel Th17. Sitokin yang meningkatkan peradangan disebut sitokin pro-inflamasi, sedangkan yang menekan disebut sitokin anti-inflamasi. ${ }^{8}$ Terdapat dua tipe stroke yaitu stroke iskemik dan stroke hemoragik. Stroke iskemik terjadi akibat aterosklerotik dan peran peradangan yang berkontribusi dalam kejadian stroke, yang dengan adanya hipoksia pada neuron akan memicu pelepasan sitokin, termasuk tumor necrosis factor-alpha (TNF- $\alpha)$ dan interleukin-10 (IL-10) dari neuron dan sel glial. Sitokin ini telah diciptakan sebagai kandidat biomarker untuk stroke. Beberapa penelitian telah menghubungkan sitokin proinflamasi dengan risiko stroke akut serta prognosis stroke yang buruk. Sitokin yang terkait stroke adalah TNF- $\alpha$, IL-1, IL-6, IL-20, ral IL10 , transforming growth factor-B (TGF-B), IL8 , interferon inducible protein-10 (IP-10) dan kimia monosit chemoatraction protein-1 (MCP1). Sedangkan IL-1 $\beta$, IL- $8, \mathrm{MCP}-1, \mathrm{TNF}-\alpha$ memperburuk cedera otak. Sitokin antiinflamasi TGF- $\beta$, IL-10, dan antagonis reseptor IL-1 (IL1Ra) tampaknya bekerja sebagai neuroprotektif. Peningkatan produksi sitokin proinflamasi dan penurunan kadar IL-10 berhubungan dengan infark luas dan hasil klinis yang buruk. ${ }^{9,14,15}$ Beberapa studi mencatat bahwa kadar tinggi dari marker inflamasi seperti C-reactive protein (CRP) dan interleukin-6 (IL-6) dihubungkan dengan keluaran yang buruk setelah stroke iskemik dan hemoragik. ${ }^{16}$ Dari table 1 dapat dilihat bahwa sitokin yang terkait stroke adalah TNF- $\alpha$, IL-1, IL-6, IL-20, IL-10, TGF-B, IL8, interferon inducible protein-10 (IP-10), dan monosit chemoatraction protein-1 (MCP-1). Sitokin yang memperburuk cedera otak adalah IL-1 $\beta$, IL-18, MCP-1, dan TNF- $\alpha$, sedangkan TGF- $\beta$, IL-10, dan IL-1 reseptor antagonis (IL1Ra) merupakan pelindung saraf. ${ }^{15}$

\section{Gangguan tidur}

Insomnia adalah ketidakmampuan untuk mendapatkan jumlah waktu tidur yang kita butuhkan, bangun dengan perasaan istirahat dan segar. Insomnia didefinisikan berdasarkan kualitas tidur dan perasaan kita setelah tidur, bukan berapa jam kita tidur atau seberapa cepat kita tertidur. Bahkan jika kita menghabiskan delapan jam semalam di tempat tidur, jika kita merasa mengantuk dan lelah pada siang hari, mungkin kita alami insomnia. Kualitas dan 
Tabel 1. Mediator Inflamasi pada Kerusakan Iskemik Serebral

\begin{tabular}{|c|c|c|}
\hline Proinflammatory mediator & $\begin{array}{l}\text { Expression during } \\
\text { stroke }\end{array}$ & Cellular sources \\
\hline \multicolumn{3}{|l|}{ Cytokines } \\
\hline TNF- $\alpha$ & $\uparrow$ & \multirow{7}{*}{$\begin{array}{l}\text { Neurons, astrocytes, microglia, endothelial } \\
\text { cell, dan leukocytes }\end{array}$} \\
\hline IL-1 $\beta$ & $\uparrow$ & \\
\hline IL-6 & $\uparrow$ & \\
\hline IL-12 & $\uparrow$ & \\
\hline IL-18 & $\uparrow$ & \\
\hline IL-20 & $\uparrow$ & \\
\hline IFN- y & $\uparrow$ & \\
\hline \multicolumn{3}{|l|}{ Chemokines } \\
\hline IL-8 & $\uparrow$ & \multirow{3}{*}{$\begin{array}{l}\text { Macrophages, endothelial cells } \\
\text { Monocytes, endothelial cells, fibroblasts } \\
\text { Activated neurons, glial cells }\end{array}$} \\
\hline IP-10 & & \\
\hline MCP-1 & $\uparrow$ & \\
\hline \multicolumn{3}{|l|}{ Cell adhesion molecules } \\
\hline ICAM-1 & $\uparrow$ & \multirow[t]{7}{*}{ Endotelial cells, leukocytes, platelets } \\
\hline VCAMs & $\uparrow$ & \\
\hline Selectins & $\uparrow$ & \\
\hline Integrins & $\uparrow$ & \\
\hline Matrix metalloproteinases & $\uparrow$ & \\
\hline MMP-2 & $\uparrow$ & \\
\hline MMP-9 & $\uparrow$ & \\
\hline Mediator anti-inflammasi & & Neurons, astrocytes, microglia, \\
\hline Cytokines & & endothelial cells, leukocytes \\
\hline TGF- $\beta$ & $\downarrow$ & T lymphocytes \\
\hline IL-1Ra & $\downarrow$ & Epithelial cells, adiphocytes \\
\hline IL-10 & $\downarrow$ & Macrophages, T lymphocytes \\
\hline
\end{tabular}

Dikutip dari: Bokhari F, et al. ${ }^{15}$

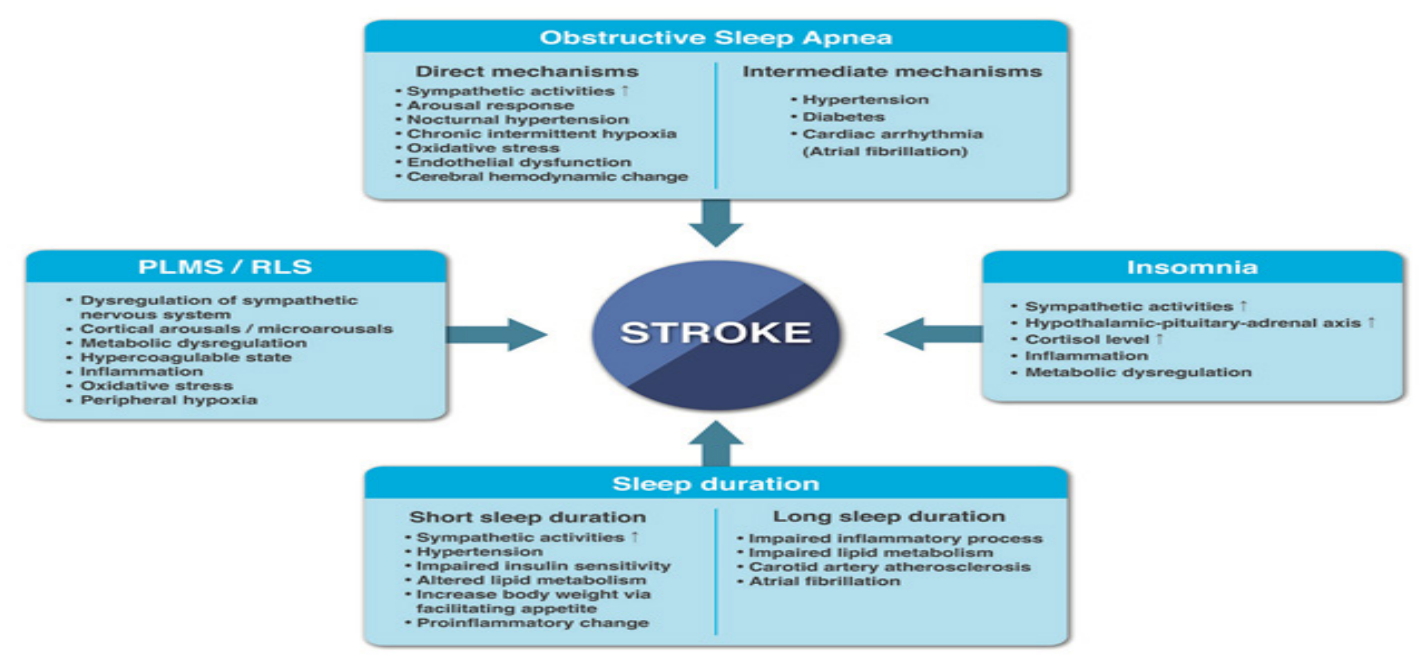

Gambar 2. Mekanisme GangguanTidur sebagai Penyebab Stroke. ${ }^{20}$ 
kuantitas tidur mempengaruhi kualitas hidup. Tidur yang tidak cukup akan menimbulkan gangguan fisik dan mental. Pada umumnya, butuh 8 jam tidur dalam sehari untuk menjaga kondisi tetap fit. ${ }^{1,7}$ Insomnia berdampak negatif pada kehidupan pekerjaan sehari-hari, mengganggu pengambilan keputusan dan dapat merusak kehidupan sosial. Dalam kebanyakan kasus, orang dengan insomnia melaporkan kualitas hidup yang lebih buruk secara keseluruhan., ${ }^{1,8}$ Sitokin berpengaruh terhadap pola tidur seperti nerve growth factor (NGF) menginduksi NREM dan REM. Sel retikuler dan neuron dalam inti trigeminal mesencephalic bersifat imunoreaktif untuk p75 dan reseptor trkA NGF. Neuron ini dapat memodifikasi REM yang diinduksi NGF. Pengaturan sitokin di otak itu rumit dan belum dipahami dengan baik. Namun demikian, beberapa zat terkait sitokin, seperti IL-1RA dan TNF dan reseptor larut IL-1 (sIL-1R) tampaknya bertindak sebagai antagonis endogen yang menghambat tidur spontan. Sitokin antisomnogenik bekerja, sebagian, dengan menghambat produksi sitokin prosomnogenik dan pelepasan zat lain terlibat dalam regulasi tidur misalnya nitrit oksida (NO). ${ }^{9,19}$

Beberapa penelitian tentang tidur bangun telah dilakukan dengan melihat NREM dan REM setelah diberikan injeksi IL-1 $\beta$, TNF- $\alpha$, dan sitokin lain dalam tidur. Injeksi IL-1 $\beta$ atau TNF- $\alpha$ eksogen dosis rendah meningkatkan NREM. Sebaliknya, penghambatan IL-1 $\beta$ dan TNF- $\alpha$ endogen, menggunakan antibodi atau inhibitor endogen seperti reseptor terlarutnya, menghambat tidur spontan juga menghambat rebound tidur setelah kurang tidur. Keduanya IL-1 $\beta$ mRNA dan TNF- $\alpha$ mRNA meningkat di otak selama kurang tidur. Baik IL- $1 \beta$ dan TNF- $\alpha$ telah dikaitkan dengan berbagai kondisi klinis yang melibatkan gangguan tidur.,19 Gangguan tidur pada pasen stroke dapat bermanifestasi dalam beberapa bentuk tergantung pada defisit neurologis spesifik yang ditimbulkan. Sleepdisorder breathing (SDB) terutama obstructive sleep apnea syndrome (OSAS) dan nocturnal oxygen desaturation merupakan gangguan tidur yang paling banyak ditemukan pada stroke yaitu $>50 \%$. ${ }^{1}$ Gangguan tidur memiliki prevalensi yang tinggi pada pasien stroke dan yang mempunyai risiko stroke. Prevalensi gangguan tidur-bangun sebesar $20-40 \%$ pada pasien yang terkena stroke. Kualitas tidur yang buruk dapat memengaruhi derajat disabilitas pada pasien stroke. Seorang peneliti mendapatkan bahwa risiko terkena stroke atau risiko kematian oleh sebab apapun lebih besar terjadi pada pasien dengan gangguan tidur terutama sleep apnea. ${ }^{1,10}$ Dari hasil seorang peneliti, didapatkan sebanyak $47 \%$ pasien melaporkankualitas tiduryang buruk. Berdasarkan lama tidur, didapatkan hanya $32,4 \%$ pasien yang melaporkan lama tidur lebih dari 7 jam semalam dalam 1 bulan terakhir. Sebanyak $80,4 \%$ pasien merasakan adanya gangguan tidur minimal 1 kali sebulan dan $15,7 \%$ lainnya mengalami setidaknya 1-2 kali gangguan tidur dalam seminggu terakhir sebelum stroke. ${ }^{1}$ Hubungan OSA dengan penyakit vaskular sebagian dimediasi oleh adanya faktor risiko vaskular utama. OSA sangat erat kaitannya dengan hipertensi, diabetes, dan obesitas, dimana ketiganya merupakan faktor penyebab stroke iskemik. ${ }^{10}$ OSA di semua tingkat keparahan dikaitkan dengan peningkatan risiko stroke pada pria. Pasien dengan 'stroke kriptogenik' memiliki insidensi OSA tertinggi, meningkatkan kemungkinan bahwa OSA dapat menjadi penyebab penting stroke iskemik dengan etiologi yang tidak diketahui.

Beberapa mekanisme disarankan untuk menjelaskan hubungan ini termasuk peningkatan aktivasi platelet, dan penurunan aliran darah otak cerebral blood flow (CBF) yang diinduksi apnea dan saturasi oksigen. Beberapa mekanisme OSA yang meningkatkan risiko stroke seperti hipoksemia, lonjakan simpatis, dan hipertensi nokturnal. Kerusakan sel endotel dapat terjadi oleh stres oksidatif selama hipoksemia yang berhubungan dengan apnea. Selain itu, fluktuasi tekanan darah (blood pressure/BP) yang besar selama kejadian obstruksi dan hipertensi yang berkelanjutan selama tidur dapat menyebabkan peningkatan turbulensi dan tekanan geser ke dinding pembuluh darah. Gairah dari tidur yang mungkin memainkan peran penting dalam jumlah 'nondipping BP dalam tidur yang menyebabkan hipertensi nokturnal. Perantara yang mungkin antara OSA dan stroke adalah perubahan aliran 
hemodinamik otak. Obstruksi dapat menyebabkan penurunan $\mathrm{CBF}$ dan gangguan autoregulasi otak. Kecepatan CBF yang menurun di wilayah arteri serebral tengah selama apnea telah dibuktikan dengan transkranial Doppler. Perubahan tekanan intratoraks selama kejadian obstruksi dapat mengurangi $\mathrm{CBF}$ yang meningkatkan risiko stroke pada pasien yang rentan. Penurunan $\mathrm{CBF}$ dan gangguan reaktivitas vasomotor telah diamati selama terjaga pada subjek dengan OSA. Mekanisme ini dapat menyebabkan serebral yang terkait dengan peningkatan lonjakan simpatis, penyakit pembuluh darah serta penyakit materi putih serebral dan menyebabkan kerusakan serebrovaskularsubklinis danperubahan struktural permanen pada otak. Mekanisme penting lainnya yang dapat menyebabkan kerusakan klinis selama stroke iskemik akut adalah Sindrom Robin Hood Terbalik (Reversed Robin Hood syndromel RHHS) sebagai salah satu mekanisme kerusakan neurologis dini pada pasien stroke iskemik akut yang terkait dengan pencurian aliran darah arteri dari otak yang iskemik ke otak yang sehat. Desaturasi oksigen ditambah dengan hiperkapnia selama obstruksi pada OSA dapat memicu fenomena pencurian darah otak ini. Dokter harus menyadari OSA sebagai etiologi potensial dari perburukan neurologis pada stroke akut. ${ }^{10,20}$

\section{Simpulan}

Gangguan tidur atau yang dikenal dengan istilah insomnia sering terjadi pada pasien stroke, yang dapat mempengaruhi keluaran stroke iskemik. Berbagai respon inflamasi dapat muncul baik karena gangguan tidurnya sendiri atau respon inflamasi yang timbul akibat proses iskemia serebral. IL-1 $\beta$ dan TNF- $\alpha$ merupakan sitokin yang melibatkan gangguan tidur, sedangkan Sitokin yang memperburuk cedera otak adalah IL-1 $\beta$, IL-18, IL-6, MCP-1, TNF- $\alpha$, dan CRP. Peningkatan sitokin tersebut akan menimbulkan luaran yang buruk pada penderita stroke. .

\section{Daftar Pustaka}

1. Sekeon SAS, Kembuan MAHN. Hubungan antara kualitas tidur dengan keparahan stroke.
Jurnal e-Clinic (eCl), Volume 3, SeptemberDesember 2015.

2. Guo Y, Li P, Guo Q, Shang K, Yan D, Du S,et al. Pathophysiology and biomarker in acute ischemic stroke a review. Tropical journal of Pharmacheutical Research December 2013; 12 (6): 1097-1105.

3. Kementrian Kesehatan Republik Indonesia. Hasil Utama Riset Kesehatan Dasar. Kemenkes. Indonesia. 2018.

4. Alrabghi L, Alnemari R, Aloteebi R, Alshammari H, Ayyad M, Al Ibrahim $M$, et al. Stroke types and management. Review Article. International Journal of Community Medicine and Public Health. 2018Sep;5(9):xxx-xxx.

5. Gebreyohannes EA, Bhagavathula AS, Abebe TB, Seid MA, Haile KT. In-hospital mortality among ischemic stroke patient in Gondar University Hospital: A retrospective cohort study. Hindawi Stroke research and treatment. 2019, Article ID 7275063,7.

6. Mir MA, Al-Baradie R, Alhussainawi MD. Pathophysiology of stroke. 2014 Nova Science Publishers, Inc.

7. Li X, Chen X, Huang W, Huang W, Li Q, Zhang H, et al. The prognostic value of serum cytokines in patients with acute ischemic stroke. Aging and Disease. 2019;10(3):54456.

8. Siniscalchi A, Gallelli L, Malferrari G, Pirritano D, Serra R, Santangelo E, et al. Cerebral stroke injury: the role of cytokines and brain inflammation. J Basic Clin Physiol Pharmacol 2014; aop.

9. Krueger JM, Madje JA, Rector DM. Cytokines in immune function and sleep regulation. HHS Public Access. HandbClin Neurol.2011; 98:229-40.

10. Wallace DM, Ramos AR, Rundek T. Sleep 
disorders and stroke. NIH Public Access. Int J Stroke. 2012 April; 7(3): 231-42.

11. Heiss WD. The Pathophysiology of ischemic stroke studied by radionuclide imaging. $\mathrm{J}$ Neurol Neuromed. 2016; 1(8): 22-8.

12. Boehme AK, Esenwa C, Elkind MSV. Stroke risk factor, genetics, and prevention. Circ Res. 2017; 120:472-95.

13. Demarin V. Pathophysiology and classification of cerebrovascular disorders. The Journal Of The International Federation Of Clinical Chemistry And Laboratory Medicine. 2020.

14. Pawluk H, Wozniak A, Kolodziejska R, Kolodziejska R, Kozakiewicsz M, Kopkowka $\mathrm{E}$, et al. The role of selected pro-inflammatory cytokines in pathogenesis of ischemic stroke. Dove Press journal: Clinical Intervention in Aging. 2020;15: 469-84.

15. Bokhari F, Butt A, Shakoori TA, Ghafoor F. TNF-alpha: a risk factor for ischemic stroke. Article in Journal of Ayub Medical College,
Abbottabad: JAMC April 2014;26(2).

16. Tuttolomondo A, Raimondo DD, Pecoraro R, Arnao V, Pinto A, Licata G. Inflammation in ischemic stroke subtypes. Current Pharmaceutical Design, 2012; 18: 4289-310.

17. Levenson JC, Kay DB, Buysse DJ. The Pathophysiology of insomnia. Journal. publication.chestnet.org. DOI: 10.1378/ chest.14-1617.

18. Singh P. Insomnia: A Sleep disorders: Its causes, symptoms and treatment. International Journal of Medical and Health Research. 2016;2(10):37-41.

19. Jewet KA, Krueger JM. Humoral sleep regulation; interleukin-1 and tumor necrosis factor. Published in final edited form as: Vitam Horm. 2012;89: 241-57.

20. Koo DL, Nam H, Thomas RJ, Yun $\mathrm{CH}$. Sleep disturbances as a risk factor for stroke. Journal of Stroke. 2018.20(1):12-32. 